\title{
Possibilities for Multispecies Approaches in Coffee Landscapes
}

\author{
Jose R. Becerra Vera ${ }^{1 *}$ \\ ${ }^{1}$ Department of Anthropology, Purdue University, West Lafayette, Indiana, USA. \\ *becerra4@purdue.edu
}

\begin{abstract}
Multispecies approaches can increase our knowledge around the social and ecological dimensions of coffee landscapes. Ethnobiologists combine the social and natural sciences to study the relationships between humans, the environment, and biota. Multispecies approaches can build from these strategies to further explore the social and biological elements that humans together with more-than-humans contribute to ecological landscapes. Using co-constitutions as a key concept, I highlight multispecies studies into agrarian worlds, review ethnobiological studies around coffee, and suggest potential research areas.
\end{abstract}

Received May 25, 2020

OPEN ӘACCESS

Accepted September 28, 2021

DOI 10.14237/ebl.12.1.2021.1706

Published November 18, 2021

Keywords Multispecies, Co-constitutions, Coffee, More-than-human, Crops

Copyright (c) 2021 by the author(s); licensee Society of Ethnobiology. This is an open-access article distributed under the terms of the Creative Commons Attribution-NonCommercial 4.0 International Public License (https://creativecommons.org/licenses/by-nc/4.0), which permits non-commercial use, distribution, and reproduction in any medium, provided the original author and source are credited.

\section{Introduction}

Ethnobiologists draw from social and natural science methods to build scientific understanding around the relationships between plants and people. While ethnobiologists collect various forms of evidence, there continues to be an emphasis on quantitative studies (Da Silva et al. 2014) with recent calls for "hypothesis-driven ethnobiology" (Gaoue et al. 2021). Multispecies researchers collect qualitative, humanistic, and other artistic evidence (e.g. https:// feralatlas.org) suitable to expand knowledge around the social roles of plants in relationship to humans. Both communities of research reach across disciplinary boundaries to study plants. While ethnobiologists more often incorporate quantitative elements in their studies (e.g. Bocinsky and Varien 2017; Flachs 2015; Juárez-López et al. 2017), multispecies researchers lean toward qualitative approaches in their investigations (e.g.; Dove 2019; Guthman 2019; Kumpf 2020).

Ethnobiologists take versatile approaches to investigate economically and culturally important crops. Examples include: experimental farming studies of maize (Zea mays) to determine how past farming communities adapted to climate challenges (Bocinsky and Varien 2017); studies that document and compare the economic botany between genetically modified and organic cotton (Gossypium birsutum) farms (Flachs 2015, 2016); and folk taxonomic studies of plant diversity (Heindorf et al. 2020) and traditional plant use (Loko et al. 2018). Similarly, ethnobiological research around coffee (Coffea spp.) includes work that highlights traditional and Indigenous cultivation knowledge (Beaucage 1997; Bandeira et al. 2002; Juárez-López et al. 2017), features coffee as an important regional cash crop to contextualize the bioecocultural heritage of other plants (Mekbib 2009), and explores coffee farm contributions to biological diversity (Bandeira et al. 2002; Juárez-López et al. 2017). These studies teach us how crops meet human needs and influence human social worlds.

Multispecies approaches open doors to investigate the social and biological contact zones of humans, plants, and other more-than-humans in agrarian worlds (Galvin 2018). Building from ethnobiological insights into the interactions between biota, environments, and people, multispecies approaches draw attention to the social dimensions that result from these relationships. Researchers can investigate the co-creation of ecological landscapes through and with crops by paying attention to this 
collective sociality (Flachs and Orkin 2019). In this short topical review, I outline multispecies approaches in agricultural crop studies, ethnobiology of coffee, and highlight the potential advantages of multispecies approaches in coffee research.

\section{Agrarian Contact Zones}

In this paper, I borrow from the concepts of contact zones and assemblages to define co-constitutions as spatial and temporal locations of world-making (Wilson 2019), where the relational context of all constituents shapes a system (Robinson and Remis 2018). Co-constitutions result from entangled human and more-than-human social and biological elements that together also participate in the production of social and ecological change. Instances of multispecies approaches in crop studies that highlight coconstitutions include Julie H. Guthman's (2019) work with strawberries (Fragaria spp.), Michael R. Dove's (2019) historical analysis with black pepper (Piper nigrum), rubber (Hevea brasiliensis), and sword grass (Imperata cylindrica), and Desirée Kumpf's (2020) investigation of tea production (Camellia spp).

Guthman (2019) describes the strawberry industry as an assemblage, for this topical review, otherwise known as a co-constitution. For Guthman, the coconstitution includes elements of political economy, scientific knowledge, migrants and labor, pathogens and chemicals, and other humans and more-thanhumans that together play a role in the fragility of the strawberry industry. Dove (2019) outlines how the introduction of black pepper, tea, and sword grass into agrarian co-constitutions expanded small holders' imaginations and cultivation strategies, often at odds with settler-colonial production regimes. Kumpf (2020) demonstrates how the lack of compensation for tea workers results in them ignoring tea tasting during production, which leads to lower quality tea. These studies highlight the role plants have on transforming human worlds. Refocusing attention to co-constitution in ecologies, where "organisms, elements, and forces cannot be considered in isolation but must always be considered in relation," (O'Gorman and Gaynor 2020).

\section{Ethnobiology of Coffee}

Coffee is the second most traded commodity worldwide and is recognized for its cultural value among producers and consumers (West 2012). Ethnobiological studies on coffee have explicitly focused on the negative economic and environmental impacts that result from neglecting Indigenous knowledge (Beaucage 1997), as well as investigated the insights from Indigenous and traditional knowledge in maintaining agroforests (Bandeira et al. 2002) and biodiversity (Juárez-López et al. 2017). Other ethnobiological studies include coffee grounds in investigations of folk remedies for injuries from stingrays (Da Silva et al. 2020). In the related field of ethnomedicine, researchers examine coffee leaves for potential human health benefits (Chen 2019). Collectively, these studies demonstrate how people make use of coffee to meet economic, biodiversity, and human health goals. Multispecies approaches can expand these strategies to gain further insight into the nuances of co-created coffee ecological and social worlds. For example, Anna L. Tsing, Andrew S. Mathews, and Nils Bubandt (2019) outline how coffee rust fungus (Hemileia vastratrix) only became an epidemic due to multispecies histories that involve capital, ecology, humans, and more-than-humans together transforming a landscape.

\section{Multispecies Openings}

Following the examples of agrarian co-constitutions help to outline essential areas of multispecies coffee research. Like Guthman's (2019) analysis with strawberries, the coffee industry results from the coconstitutions between political, social, economic, and biological elements. Dove's (2019) studies with pepper highlights the role of cash crops with colonial histories of displacement and local innovation, as also seen with coffee. Kumpf's (2020) investigation with tea sheds light on how coffee ecologies connect to labor and production regimes that influence multispecies co-constitutions that affect coffee quality and taste. Coffee agriculture includes various cultivation strategies linked to political, social, colonial, economic, biological, and ecological histories. More-than-humans are inseparable from these histories and have an active role in shaping coffee landscapes. Similarly, cultivation strategies impact more-than-humans. Multispecies approaches can provide the platform to observe these different dimensions. Studying coffee landscapes as multispecies co-constitutions presents opportunities to enhance our understanding of the biological and social dimensions of human, plant, pathogen, chemical, and other more-than-human ecologies. 


\section{Conclusion}

In sum, ethnobiological studies provide insight into how plants meet human needs and interests. Multispecies approaches offer researchers the opportunity to expand on these studies to include how the interactions between humans, plants, and more-than-humans together shape and transform landscapes. Applying a multispecies approach to crop studies highlights the effects of more-than-humans on ecological and social elements in agrarian worlds. This offers a view beyond ecological change as an effect of human manipulation over the environment. Studying coffee co-constitutions has theoretical and methodological implications for humans and morethan-humans. While climate change discourse centers humans as the main drivers in environmental change, it also draws attention to the interlinked elements of the social and biological world. Multispecies studies of coffee can provide insight into these interlinked elements and relationships that together form ecological landscapes. This can expand knowledge around the relational contexts in coffee ecologies and help identify what multispecies collaborations are impacted by climate change. As scholars from different disciplines incorporate a multispecies approach to coffee research, they must also expand methodological toolkits to address the social and biological elements that form coffee ecologies. In this aspect, studying coffee co-constitutions can benefit from the ethnobiological skill of linking the social and natural sciences (Quinlan and Quinlan 2016).

\section{Acknowledgments}

Thank you, Dr. Andrew Flachs, for the continued support and valuable feedback on my drafts for this manuscript. I would also like to thank Dr. Maria Bruno, the editor, who has been extremely helpful throughout this process. I am especially grateful for the comments and feedback from the anonymous reviewer. Their suggestions were truly instrumental for improving this manuscript, thank you.

\section{Declarations}

Permissions: None declared.

Sources of funding: None declared.

Conflicts of Interest: None declared.

\section{References Cited}

Bandeira, F. P., Lopez, B.J. and Toledo, V. M. 2002. Tzotzil Maya Ethnoecology: Landscape Perception and Management as a Basis for Coffee Agroforest Design. Journal of Ethnobiology 22(2):247-272.

Beaucage, P., and Taller de Tradición Oral, CEPEC. 1997. Integrating Innovation: The Traditional Nahua Coffee-Orchard. Sierra Norte de Puebla, Mexico. Journal of Ethnobiology 17(1):45-67.

Bocinsky, R. K., and Varien, M. D. 2017. Comparing Maize Paleoproduction Models with Experimental Data. Journal of Ethnobiology 37(2):282-307. DOI:10.2993/0278-0771-37.2.282.

Chen, X. 2019. A Review on Coffee Leaves: Phytochemicals, Bioactivities and Applications. Critical Reviews in Food Science and Nutrition 59 (6):1008-1025.

DOI:10.1080/10408398.2018.1546667.

Da Silva, G. A., Poscai, A. N., and da Silva Casas, A. L. 2020. Injuries Caused by Freshwater Stingrays in the Western Amazon. Ethnobiology Letters 11(1):1-13. DOI:10.14237/ebl.11.1.2020.1586.

Da Silva, V. A., do Nascimento, V. T., Soldati, G. T., Medeiros, M. F. T., and Albuquerque, U. P. 2014. Techniques for Analysis of Quantitative Ethnobiological Data: Use of Indices. In Methods and Techniques in Ethnobiology and Ethnoecology, edited by U. P. Albuquerque, L. V. F. Cruz da Cunha, R. F. P. de Lucena, and R. R. Nobrega Alves, pp. 379395. Springer Protocols Handbooks, Humana Press, New York, NY. DOI:10.1007/978-1-4614-86367_24.

Dove, M. R. 2019. Plants, Politics, and the Imagination Over the Past 500 Years in the IndoMalay Region. Current Anthropology 60(S20):S309S320. DOI:10.1086/702877.

Flachs, A. 2015. Persistent Agrobiodiversity on Genetically Modified Cotton Farms in Telangana, India. Journal of Ethnobiology 35(2):406-426.

Flachs, A. 2016. The Economic Botany of Organic Cotton Farms in Telangana, India. Journal of Ethnobiology 36(3):683-713. DOI:10.2993/02780771-36.3.683.

Flachs, A., and Orkin, J.D. 2019. Fermentation and the Ethnobiology of Microbial Entanglement. Ethnobiology Letters 10(1):35-39. DOI:10.14237/ebl.10.1.2019.1481.

Galvin, S. S. 2018. Interspecies Relations and Agrarian Worlds. Annual Review of Anthropology 47:233-249. DOI:10.1146/annurev-anthro-102317-050232. 
Gaoue, O. G., Moutouama, J. K., Coe, M. A., Bond, M. O., Green, E., Sero, N. B., Bezeng, B. S., and Yessoufou, K. 2021. Methodological Advances for Hypothesis-Driven Ethnobiology. Biological Reviews 96(5):2281-2303. DOI:10.1111/brv.12752.

Guthman, J. 2019. Wilted: Pathogens, Chemicals, and the Fragile Future of the Strawberry Industry (Vol. 6). University of California Press, Berkeley, CA. DOI:10.2307/j.ctvp7d4bc.

Heindorf, C., van't Hooft, A., Reyes-Agüero, J. A., and Martínez, J. F. 2020. Folk Taxonomy of the Inter-and Intraspecific Edible Plant Diversity of Huastec Mayan Farmers in Mexico. Journal of Ethnobiology 40(4):552-568. DOI:10.2993/02780771-40.4.552.

Juárez-López, B. Velázquez-Rosas, N., and LópezBinnqüist, C. 2017. Tree Diversity and Uses in Coffee Plantations of a Mixe Community in Oaxaca, Mexico. Journal of Ethnobiology 37(4):765-778. DOI:10.2993/0278-0771-37.4.765.

Kumpf, D. 2020. Organic Taste and Labour on Indian Tea Plantations. Social Anthropology 28(4):789 -802. DOI:10.1111/1469-8676.12951.

Loko, L. E. Y., Toffa, J., Adjatin, A., Akpo, A. J., Orobiyi, A., and Dansi, A. 2018. Folk Taxonomy and Traditional Uses of Common Bean (Phaseolus vulgaris L.) Landraces by the Sociolinguistic Groups in the Central Region of the Republic of Benin. Journal of Ethnobiology and Ethnomedicine 14(1):1 -15. DOI:10.1186/s13002-018-0251-6.
Mekbib, F. 2009. Folksong Based Appraisal of Bioecocultural Heritage of Sorghum (Sorghum bicolor (L.) Moench): A New Approach in Ethnobiology. Journal of Ethnobiology and Ethnomedicine 5(1):1-19. DOI:10.1186/1746-4269-519.

O'Gorman, E., and Gaynor, A. (2020). More-ThanHuman Histories. Environmental History 25(4):711735. DOI:10.1093/envhis/emaa027.

Robinson, C. A. J., and Remis, M. J. 2018. Engaging Holism: Exploring Multispecies Approaches in Ethnoprimatology. International Journal of Primatology 39(5):776-796. DOI:10.1007/s10764-018 -0036-8.

Quinlan, M. B., and Quinlan, R. J. 2016. Ethnobiology in One Health. Ethnobiology Letters 7(1):59-61. DOI:10.14237/ebl.7.1.2016.680.

Tsing, A. L., Mathews, A. S., and Bubandt, N. 2019. Patchy Anthropocene: Landscape Structure, Multispecies History, and the Retooling of Anthropology: An Introduction to Supplement 20. Current Anthropology 60(S20):S186-S197. DOI:10.1086/703391.

West, P. 2012. From Modern Production to Imagined Primitive: The Social World of Coffee from Papua New Guinea. Duke University Press, Durham, NC.

Wilson, H. F. 2019. Contact Zones: Multispecies Scholarship Through Imperial Eyes. Environment and Planning E: Nature and Space 2(4):712-731. DOI:10.1177/2514848619862191. 